\title{
Adoption of dairy farming technologies by small farm holders: practices and constraints
}

\author{
MA Quddus
}

Department of Agricultural Statistics, Bangladesh Agricultural University, Mymensingh-2202, Bangladesh

\begin{abstract}
In Bangladesh, usually, small scale farmers are not adopted to use all kinds of improved technologies in dairy farming. But, high level of technology adoption has a direct impact on milk yield and household's income generation as well as dairy development. The objectives of this study was to determine the causes of adoption and non adoption of high yielding breed, the level of practices and constraints in adopting the improved technologies. The study was carried out in three different agro-ecological zones and 180 dairy cattle farmers were interviewed. Self practiced dairy technologies were listed, adoption score for each technology and adoption index for each farmer were studied. One-fourth farmers used artificial insemination for breeding purpose and two-fifth belonged to medium or high level of technology adoption. Only 35\% farmers adopted crossbred cows and some others upgraded indigenous with exotic breeds. About $17.5 \%$ rural farmers and $70 \%$ semi-urban farmers reared crossbred cows and rural farmers are reluctant to utilize all kinds of improved technologies. Secondary and higher educated farmers were 9.7 times more likely to be adopting improved technologies compared to illiterate farmers. Top ranked constraints were ill equipped and negligible services at Al centre, no provision for testing of animals, poor knowledge of farmers about health care of animals and inadequate knowledge about proper feeding and balanced ration. Need more knowledge on improved technologies through training, availability of reliable and continuous technical assistance, availability and low price of concentrate feeds, increased and timely provision of medicine, increasing Al facilities, providing pure breed and strengthening extension services were the main suggestions from farmers.
\end{abstract}

Key words: Adoption, cattle farmers, constraints, technologies

Bangladesh Animal Husbandry Association. All rights reserved. Bang. J. Anim. Sci. 2012. 41 (2): 124-135

\section{Introduction}

Dairy development in developing countries has played a major role in increasing milk production, improving income level in rural areas, generating employment opportunities and improving the nutritional standards of the people, especially for small and marginal farmers. Low and unreliable income from cash crops suggest that alternative farming activities should be developed. This is in spite of indications that there is a potential for dairy development, and dairy can reduce the level of poverty. However, smallholder dairy production is becoming increasingly important and it contributes magnificently to the improvement of the livelihoods of rural people. Higher level of technology adoption is associated with better milk yield and improved dairying has a direct impact on income generation, poverty alleviation and availability of animal protein. Thus, to increase the milk production existing dairy technology should be adopted in the small household dairy farms. Dairying is growing faster in Bangladesh but facing the problems of inefficient management practices and health care, lack of high quality breeds, lack of proper breeding programme to improve the existing dairy cattle resource, high input and low output prices leading to lower productivity (Uddin et al. 2010).

The dairy technologies encompass the use of crossbred animals, improved feed technology and improved management (Mohamed et al. 2004). But cattle farming in rural Bangladesh are constituted mainly from smallholder farming system being managed in traditional ways. The effect of several technical (breeds, artificial insemination, vaccination, etc) and sociodemographic factors would be beneficial to improve the dairy production. Understanding the factors affecting farmers' adoption of dairy technology is critical to success of development and implementation of policies and programmes in dairy industry development. Previous adoptionoriented research has examined the use and diffusion of dairy-related technologies (Metz et al. 1995, Nicholson et al. 1999; Mohi and Bhatti 2006; Mekonnen et al. 2009) and the factors affecting adoption on smallholder farms (Irungu et al. 1998; Jera and Ajayi. 2008). However, numerous studies have found that constraints 
imposed by the factors those influence the awareness, availability, costs, benefits and risks associated with the different livestock technologies and management practices (Benin et al. 2003). But surprisingly little work has been done to examine the status and constraints of adoption of dairy technologies in rural smallholder dairy farms in Bangladesh.

The nation still has the potential to meet the growing demand for milk, but the immediate need is to adopt and follow better technologies of dairy farming. To increase the country's milk output, a judicious strategy of focusing on high yielding breeds and improved management technology should be adopted for considerable dairy development. Before that, it is need to know the base-line information of existing features of technology adoption by the small dairy farmers and the related constraints to adopt these technologies. The present study is, therefore, undertaken to identify the causes of adopting and non-adopting crossbred cattle, adoption level, effect of adoption on milk yield, factors that influence in adoption and various constraints encountered by the farmers.

\section{Materials and Methods}

The study was carried out in three different agroecological zones hilly highlands (Jinaigati Upazila under Sherpur District), riverside lowlands (Dewangonj Upazila under Jamalpur District) and Semi-urban areas (Sadar, Mymensingh). Zones were selected by using purposive sampling procedure keeping in view the operational feasibility. Two adjacent villages were selected from each zone where small dairy farms were available. One hundred and eighty (sixty from each zone) dairy cattle farmers were selected and interviewed by a cross-sectional household visits with the help of a structured interview schedule that was pre-tested and adjusted prior to the objectives of the study. Data were collected from October 2010 to March 2011.

Self practiced dairy technologies (crossbred cows, housing status, technology uses in feeding, treatment, etc.) were listed and their adoption level in percentage of farmers was measured. Further, adoption score for each technology was measured by scoring the level of technology used. Adoption index for each farmer was computed by score obtained for individual divided by total obtainable score and expressed as percentage. The dairy farmers were categorized into four categories (no adopters, low adopters, medium adopters and high adopters) on the basis of their level of adoption measured in terms of adoption index. Combination of the farmers of the first two categories was named as non-adopters and the last two categories was named as adopters. The level of constraints was measured by number of farmers perceiving the constraint divided by total number of farmers and expressed as percentage.

Data were analysed by using Statistical Package for Social Sciences (SPSS) 16.0 computer software package. A characterisation was done using contingency tables (cross tabulation) to compare the proportion of adopters and nonadopters in respect of a particular characteristic. Chi-square tests were carried out to assess relationships between adoption and socioeconomic variables. Usually, standard linear regression model (logit model) is used in a binary choice (adoption versus non-adoption of technology) of outcomes. Factors included in the model are exogenous i.e. currently taken as given by the households. The model provides empirical estimates of how change in these exogenous variables influences the probability of adoption and used to assess the effectiveness of technology adoption (Nkonya et al. 1997).

Thus, a logistic function including odds ratios was used to derive coefficients of explanatory variables likely to influence farmer's attitudes to technologies adoption. For this analysis, level of technology adoption was the dependent variable and ten selected socioeconomic factors were the independent variable. Adoption level is a dichotomous (adopter $=1 /$ non-adopter $=0$ ) variable and all of the independent variables are also categorical. Correlation analysis between independent variables was done to look into their interrelationship whether any multi-collinear existed. Farmers were assigned 1 who used medium or higher level of technology adoption otherwise assigned 0 . The binary logistic model used in the study is specified as follows:

$$
P=p(Y=1 / X)=\frac{e^{\beta_{0}+\sum_{i=1}^{10} \beta_{i} X_{i}}}{1+e^{\beta_{0}+\sum_{i=1}^{10} \beta_{i} X_{i}}}
$$

And,

$$
1-P=p(Y-0 / X)=\frac{1}{1+e^{\beta_{0}+\sum_{i=1}^{10} \beta_{i} X_{i}}}
$$




\section{Adoption of dairy farming technologies}

A transformation of $\mathrm{P}$ known as the logit transformation and is defined as

Logit $\mathrm{P}=\log \left[\frac{P}{1-P}\right]=\beta_{0}+\sum_{i=1}^{10} \beta_{i} X_{i}$

In the model;

$Y_{\mathrm{i}}$ : Level of technology adoption ( $1=$ adopters, 0 $=$ non-adopters)

$\mathrm{X}_{1}$ : Age: age group of the farmers $(0=<30$ years, $1=30-49$ years $2=50$ years and above)

$\mathrm{X}_{2}$ : Education; education level of the farmers ( 0 = illiterate, $1=$ primary, $2=$ Secondary + )

$\mathrm{X}_{3}$ : Farm size; crop land $(0=<0.20$ ha, $1=$ 0.20-0.99 ha, $2=1$ ha and more)

$\mathrm{X}_{4}$ : Income; household's total income $(0=$ <Tk.5000, 1 =Tk.5000-14999, 2 = Tk.15000+)

$X_{5}$ : Earning member in the household ( $0=1-2$ members, $1=>2$ members)

$\mathrm{X}_{6}$ : Experience in dairy farming $(0=<10$ years, $1=10-19$ years, $2=20$ years and above)

$\mathrm{X}_{7}$ : Credit received for dairy farming $(0=$ no, $1=$ yes)

$\mathrm{X}_{8}$ : Extension service received ( $0=$ No, $1=$ yes $)$

$\mathrm{X}_{9}$ : Livestock as a main source of income $(0=$ no, 1 = yes)

$\mathrm{X}_{10}$ : Agro-ecological zones $(0=$ hilly, $1=$ river flooded, 2 = semi-urban).

\section{Results and Discussion}

\section{Farm household characteristics}

Age of farmers and their past experience in dairying are interrelated with technology adoption. The majority of respondents belonged to 30-49 years of age and farming experience of the $66 \%$ respondent was less than 10 years (Table 1). P-values of Chi-square statistics indicate that these two characteristics were significantly associated with adoption categories. Probability of adoption decreased with the increase of age of the household head because older farmers may be more reluctant to adopt new technologies or practices (Feder et al. 1985). Only $22.2 \%$ farmers had higher secondary or above education which is better than the findings of Mandal et al. (2009). About $46.1 \%$ farmers were small land holding and $35.6 \%$ were medium ( $<1 \mathrm{ha})$ and there had insignificant association between land size and adoption of dairy. The finding is contrary to the study of Staal et al. (2002), which found a positive correlation between these two qualitative variables. Only 15 percent farmer's main source of income was dairy farming, 14 percent farmers received credit and 11 percent farmers received extension services (Table 1). Also these three characteristics and study zone were significantly associated with adoption level.

\section{Adoption and non-adoption of crossbred cattle}

The study also sought to understand the motivations for the adoption decision regarding improved dairy cattle. The most important reason indicated by households that acquired for more milk for sale to have a higher and more regular income. Higher demand for milk in markets was also an important reason for acquiring crossbred cattle. These findings supported by Nicholson et al. (1999). Having source of artificial insemination and or bulls, the prestige of owning a crossbred cow and or bull and having source of concentrate and fodder were the next important reason for adoption of crossbred cattle (Table 2 ).

Out of 180 dairy cattle owners, 117 households had never owned crossbred cattle. Most of them wanted to acquire crossbred cattle, but had not done so. Thus, many non-adopting households consider ownership of crossbred cattle beneficial but were prevented from adopting dairying for some reason. The principal reason for nonadoption was high cost of inputs mentioned by 86 households (Table 3). Need to devote time, management complexity and high price of quality feeds were the next reason for non-adoption. Seventy three $(62.4 \%)$ households indicated that lack of money to purchase animal was somewhat important in their decision not to adopt, given that they had insufficient cash to buy a crossbred cattle. This was the principal reason in Kenya reported by Nicholson et al. (1999). The next reason was disease risk which indicates that risk factor also influenced their decision not to adopt crossbred cattle. Other reasons offered by a large number of households included 'need more labour and it is expensive', 'no money for cattle housing', 'inadequate technical advice', 'lack of information on how to manage animals' and lack of awareness. Lack of education, selling of milk is a problem, lack of animals available for purchase, improper communication, insufficient land for housing and climate condition were the minor reasons for non adoption of crossbred cattle. 
Quddus (2012) Bang. J. Anim. Sci. 41 (2): 124- 135

Table 1. Socioeconomic characteristics of the sample farmers

\begin{tabular}{|c|c|c|c|c|c|}
\hline Characteristics/Category & Adopters & Non-adopters & Total & Chi-square & p-value \\
\hline \multicolumn{6}{|l|}{ Age (Year) } \\
\hline$<30$ & 6 & 18 & 24 & 6.006 & 0.050 \\
\hline $30-49$ & 37 & 65 & 102 & & \\
\hline 50 and above & 28 & 26 & 54 & & \\
\hline \multicolumn{6}{|l|}{ Education level } \\
\hline Illiterate & 11 & 62 & 73 & 40.128 & 0.001 \\
\hline Primary & 30 & 37 & 67 & & \\
\hline Secondary+ & 30 & 10 & 40 & & \\
\hline \multicolumn{6}{|l|}{ Farm size (ha) } \\
\hline$<0.20$ & 40 & 43 & 83 & 5.341 & 0.069 \\
\hline $0.20-0.99$ & 19 & 45 & 64 & & \\
\hline 1 and above & 12 & 21 & 33 & & \\
\hline \multicolumn{6}{|c|}{ Household income (Tk./ month)* } \\
\hline$<5000$ & 10 & 75 & 85 & 54.995 & 0.001 \\
\hline $5000-14999$ & 33 & 25 & 58 & & 0.001 \\
\hline 15000 and above & 28 & 9 & 37 & & \\
\hline \multicolumn{6}{|l|}{ Earning member } \\
\hline 1 to 2 & 39 & 93 & 132 & 20.307 & 0.001 \\
\hline$>2$ & 32 & 16 & 48 & & \\
\hline \multicolumn{6}{|c|}{ Farming experience (Year) } \\
\hline$<10$ & 36 & 83 & 119 & 15.846 & 0.001 \\
\hline $10-20$ & 16 & 18 & 34 & & \\
\hline 20 and above & 19 & 8 & 27 & & \\
\hline \multicolumn{6}{|l|}{ Credit received } \\
\hline No & 55 & 100 & 155 & 7.329 & 0.007 \\
\hline Yes & 16 & 9 & 25 & & \\
\hline \multicolumn{6}{|c|}{ Extension service received } \\
\hline No & 56 & 104 & 160 & 11.909 & 0.001 \\
\hline Yes & 15 & 5 & 20 & & \\
\hline \multicolumn{6}{|c|}{ Livestock as a main source of income } \\
\hline No & 48 & 105 & 153 & 27.823 & 0.001 \\
\hline Yes & 23 & 4 & 27 & & \\
\hline \multicolumn{6}{|l|}{ Locations } \\
\hline Hilly & 5 & 55 & 60 & 63.822 & 0.001 \\
\hline River flooded & 19 & 41 & 60 & & \\
\hline Semi-urban & 47 & 13 & 60 & & \\
\hline
\end{tabular}

*1\$ was equivalent to Tk.70 during the period of data collection

\section{Adoption level of improved dairy farming practices}

Small farmers keep 1-2 milch animals of low genetic production potential, follow traditional feeding systems, sometimes fed concentrate to the lactating animals and recently adopt the use of balanced concentrate mixtures for feeding milking cows (Khan et al. 2009). A large number of dairy farmers are almost ignorant about improved management practices and the adoption level of technologies is found to be very low. Adopters of all improved technologies, management practices, and production systems other than grazing achieve higher milk production than do non-adopters (Khanal et al. 2010). The extent of adoption of different dairy husbandry practices in the areas of feeding, housing, breeding, cleaning and preventive and curing measures are shown in Table 4.
Proper and better breeding helps in developing good dairy herd and getting good returns too. It is apparent from Table 4 that only 35\% farmers adopted crossbred cows as it is a 'high cost input' in dairy husbandry and most of them practiced artificial insemination. Artificial insemination (Al) has become a general breeding method in dairy production and $25.6 \%$ farmers adopted for using this method. Out of 63 farmers having crossbred cow, 43 percent identified having technical skill, 63.5 percent having attitude towards change and 33.3 percent having well exposure to other farmers (not shown in table). A few numbers of crossbred owner practiced natural breeding, might be due to their negative attitude towards artificial insemination. This fact was supported by Shivmurthy and Nataragu (1994). In addition to this, a few numbers of farmers replace indigenous cows with few high yielding genotypes, by upgrading with exotic breeds. 


\section{Adoption of dairy farming technologies}

Table 2. Causes of adoption of crossbred cattle by the small farm holders $(N=63)$

\begin{tabular}{|c|c|c|c|}
\hline Causes & Frequency & Percent & Rank \\
\hline More milk for family consumption only & 6 & 9.5 & $\mathrm{XI}$ \\
\hline More milk for consumption and sale surplus milk & 18 & 28.6 & VII \\
\hline More milk for sale (regular and higher income) & 39 & 61.9 & 1 \\
\hline High demand for milk in markets & 34 & 54.0 & II \\
\hline Having formerly training / Extension work & 14 & 22.2 & $\mathrm{IX}$ \\
\hline Having source of concentrate and fodder & 21 & 33.3 & $\mathrm{~V}$ \\
\hline Having source of Al / Bulls & 31 & 49.2 & III \\
\hline Bull to cross breeding with local cows & 19 & 30.2 & VI \\
\hline Bull to offer services to other farmers & 16 & 25.4 & VIII \\
\hline Prestige of owing crossbred cow and or Bull & 22 & 34.9 & IV \\
\hline Others said it was a good idea & 11 & 17.5 & $\mathrm{x}$ \\
\hline
\end{tabular}

Table 3. Reasons for not Adopting Crossbred Cattle by the Owner of Local Breed ( $N=117)$

\begin{tabular}{lccc}
\hline Reasons & Frequency & Percent & Rank \\
\hline Lack of education & 38 & 32.5 & XI \\
Lack of awareness & 41 & 35.0 & X \\
Lack of money to purchase animal & 73 & 62.4 & IV \\
No money for cattle housing & 55 & 47.0 & $\mathrm{VII}$ \\
High price of quality feeds & 78 & 66.7 & $\mathrm{III}$ \\
Need more labor and it is expensive & 64 & 54.7 & $\mathrm{VI}$ \\
Insufficient land for housing & 20 & 17.1 & $\mathrm{VX}$ \\
High cost of inputs & 86 & 73.5 & $\mathrm{I}$ \\
Lack of animals available for purchase & 27 & 23.0 & $\mathrm{XIII}$ \\
Lack of information on how to manage animals & 45 & 38.5 & $\mathrm{IX}$ \\
Inadequate technical advice & 48 & 41.0 & $\mathrm{VIII}$ \\
Disease risk & 68 & 58.1 & $\mathrm{~V}$ \\
Improper communication & 21 & 18.0 & $\mathrm{IVX}$ \\
Climatic condition & 18 & 15.4 & $\mathrm{VXI}$ \\
Need to devote time and management complexity & 81 & 69.2 & $\mathrm{II}$ \\
Selling of milk is a problem & 34 & 29.0 & XII \\
\hline
\end{tabular}

Table 4. Dairy cattle technology used by farmers and milk yield

\begin{tabular}{llccccc}
\hline \multirow{2}{*}{ Technology } & Category of & Proportion of farmers & \multicolumn{3}{c}{ Milk yield } \\
\cline { 2 - 7 } & technology use & Number & $\%$ & Mean & SD & p-value \\
& & & & (Liter) & & \\
\hline Feed & Traditional & 106 & 58.9 & 2.3 & 2.60 & 0.001 \\
& Improved & 60 & 33.3 & 5.8 & 3.58 & \\
& Recommended & 14 & 7.8 & 10.0 & 3.81 & 0.001 \\
\hline Cow-shed & Traditional & 87 & 48.3 & 1.4 & 1.12 & \\
& Improved & 74 & 41.1 & 5.7 & 3.57 & \\
& Recommended & 19 & 10.6 & 9.9 & 2.90 & \\
\hline Breed & Indigenous & 117 & 65.0 & 1.5 & 0.63 & 0.001 \\
& Crossbred & 63 & 35.0 & 8.9 & 2.43 & \\
\hline Breeding method & Natural & 134 & 74.4 & 2.3 & 2.34 & 0.001 \\
& Al & 46 & 25.6 & 9.2 & 2.53 & \\
\hline Preventive measure taken & Yes & 91 & 50.6 & 6.6 & 3.86 & 0.001 \\
(vaccine) & No & 89 & 49.4 & 1.6 & 1.46 & \\
\hline Improved curing measure & Yes & 54 & 30.0 & 8.0 & 3.55 & 0.001 \\
taken (Veterinary treatment) & No & 126 & 70.0 & 2.4 & 2.53 & \\
\hline Cleaning & Regular & 64 & 35.6 & 6.3 & 4.31 & 0.001 \\
& Irregular & 116 & 64.4 & 2.9 & 2.94 & - \\
\hline Overall & & 180 & 100 & 4.1 & - & - \\
\hline
\end{tabular}


Feeding, housing and record keeping are the most important aspects of dairy management. Main feed sources for local breeds were grazing, especially in rural farms. Crop residues, concentrate mixed feeds and recommended ration feeds were used only for crossbreds. From Table 4 it is clear that majority of the farmers did not follow the recommended feeding practices. Only $7.8 \%$ farmers fed their cows recommended quality of feed and $33.3 \%$ fed improved feed (concentrate mixed). About $54 \%$ farmers fed their cattle with concentrate but the recommended ration was not given (Sathiadhas et al. 2003). Around $59 \%$ of the farmers fed their cattle traditional way. Most of the farmers did not follow a judicious combination of concentrates and green fodder, resulting in imbalance in nutrition. It is seen that only $10.6 \%$ farmer maintained recommended cow-shed and $41.1 \%$ made improved cow-shed. A large portion of farmers $(48.3 \%)$ made traditional i.e. unscientific cow-shed due to their inability to maintain it. Cattle sheds were usually straw and bamboo made and some cases tin-shed in rural areas and semi-pucca in urban location.

Health care practices are often adopted by small farmers to a fairly good degree because of the knowledge of farmers and visibility of results in this case. Around $50 \%$ farmers taken preventive measures, vaccination, and $30 \%$ farmers treated their cows by veterinary doctors. The 'no cost' practices like regular cleaning, grooming, deworming of calves, disease control practices and hygienic steps before milking were not done by most of the farmers. Maintaining good records of dairy cows like date of birth, breeding dates, vaccinations, past health problems, treatment given, daily milk yield and other relevant data is essential for scientific and improved dairy farming. But there was no dairy farmer in the study area who maintained any records related to dairy animals. Lack of time to spare, low literacy rate and lack of training might have attributed to low adoption and maintenance of proper dairy management records by farmers. Similarly, no farmers adopted cattle insurance practices. Clean milk production is an important part of any dairy operation and has many positive benefits to the dairy farmers. But there was no sufficient information about clean milking from the study areas.

It was evident that in the study area, 17.5, 13.3, 25.8 and $16.7 \%$ of the rural farmers used crossbred cows, Al, improved feeds and veterinary treatment respectively, whereas these figures were $70,50,71.6$ and $56.7 \%$ respectively in the semi-urban dairy farming (Fig 1). Also use of cow-shed, vaccination and cleaning showed the equivalent results. These results indicate that rural dairy farmers are reluctant to utilize the technologies due to time consuming, botheration of the process and financial in availability.

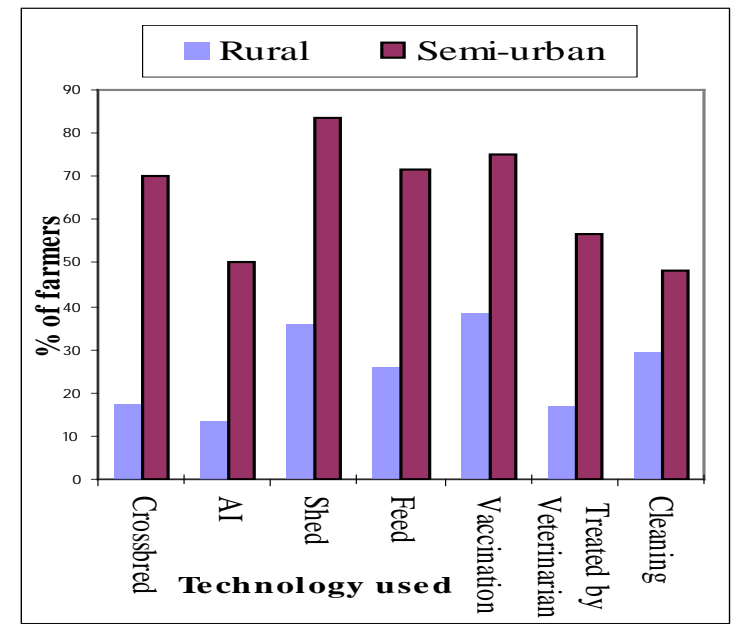

Figure 1. Technology used by the rural and semiurban farmers

\section{Effect of adoption on milk yield}

The difference in milk production performance between technology adopters and non-adopters is an established fact: hence the effect of technology adoption on milk yield was assessed in different adoption categories separately. Milk yield, both in local and crossbred cows, increased with the number of dairy technologies adopted by the smallholder farmers. However, the rate of increase was significantly different between the two breed groups (Table 4). The use of Al and knowledge of genetic upgrading and crossbreeding on smallholder dairy farms has led to increased milk production. As shown in Table 4, the average milk yield was 9.2 liter/d/cow by using $\mathrm{Al}$, whereas this figure was $2.3 \mathrm{liter} / \mathrm{d} / \mathrm{cow}$ by using natural breeding method, which is also due to indigenous cow. The yield was lower compared to the $13 \mathrm{~kg} / \mathrm{d} / \mathrm{cow}$ reported by Luthi et al. (2006) and Suzuki (2005). It is a challenge for smallholder farmers to be successful with the breeding management of crossbred cows which is vital for profitable production 


\section{Adoption of dairy farming technologies}

An improvement of feeding systems is an important prerequisite for increased profitability of dairy production since the cost of feeding accounts for 40-60\% (Devendra 2002; Man 2001) of the total cost of milk production. The average milk yields were obtained 10.0, 5.8 and 2.3 liter/d/cow by using recommended, improved and traditional methods of feeding system respectively and this difference was statistically significant (Table 4). Similarly, significant difference of milk yields was obtained between three types of cow-sheds. There is a distinct relationship between good dairy health and profits in dairying. Farmer's goal must be to prevent diseases before they occur and experienced veterinarian with dairy animal health expertise is required for best results. Farmers who treated their cows with veterinarian got higher milk yield not only due to treatment, also due to rare crossbred cow and other improved technologies.

The regression analysis indicate that the rate of increase in milk yield was 1.32 times higher when the number of technologies increased by one unit (Fig 2). High value of $R^{2}(0.766)$ indicates that technology used by the farmers as a whole had greater contribution in milk yield. The positive association between the number of technologies adopted and milk yield in both indigenous and crossbred cows is an agreement with the reports of Reynolds et al. (1996). Toolsee and Boodoo (2001) also reported improved milk yield with adoption of concentrate feeds.

It is evident from the Table 5 that majority of the $(60.6 \%)$ respondents belonged to no or low adopter categories. The remaining respondents were divided almost equally between medium (20\%) and high (19.6\%) adopter categories. High adoption of technology was $17 \%$ in Haveri district of Karnataka (Halakatti et al. 2007). The possible reason might be due to positive and significant relationship of most of the socioeconomic variables with adoption behaviour. During the course of investigation it was found that most of the respondents belonged to 'no' or 'low' level categories with respect to the various socioeconomic variables considered for the study. These socioeconomic variables are capable of inducing change in the mental ability of the farmers which facilitate them to detect the innovations floating in the environment of their own development.
Table 5. Level of adoption of dairy technology by the farmers

\begin{tabular}{lccc}
$\begin{array}{l}\text { Level of } \\
\text { adoption }\end{array}$ & $\begin{array}{c}\text { Adoption } \\
\text { Index }\end{array}$ & $\begin{array}{c}\text { Number of } \\
\text { farmers }\end{array}$ & $\%$ \\
\hline No & 0 & 55 & 30.6 \\
Low & $>0$ to $<35$ & 54 & 30.0 \\
Medium & 35 to $<70$ & 36 & 20.0 \\
High & 70 and above & 35 & 19.4 \\
\hline
\end{tabular}

\section{Factors affecting adoption}

Correlation coefficients between farm household characteristics are shown in Table $6(r=-0.044$ to $0.347, p<0.05, p<0.01)$. Lower values of correlation coefficients between all the independent variables show no any multicollinearity was existed. The values of $\beta$ coefficients (Table 7) indicated the amount of decrease or increase of adoption level in terms of increase in the level of independent variables from lower level to upper level. Adoption of dairy technology is negatively associated with farmer's aged group and farm size but positively associated with level of farmer's education and farming experience; household income and earning members. Cicek et al. (2007) found that the age and education level of the producer play a positive role in adoption of the technological innovation in dairy cattle breeding.

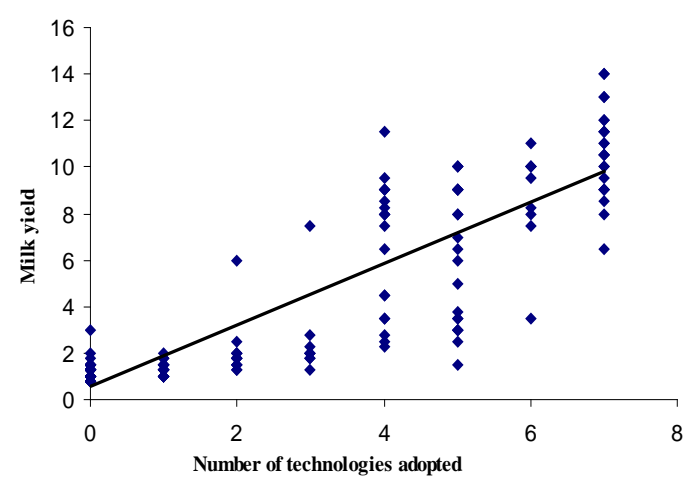

Figure 2. Effect of technologies adoption on milk yield

The odds ratios of adoption were 47 and $36 \%$ less likely among the farmers aged group 30-49 years and above 50 years respectively compared to aged group less than 30 years. Primary educated farmers were 2.26 times and above primary level educated farmers were 9.73 times more likely to be adopting improved technologies compared to illiterate farmers. This result indicates that most of the illiterate dairy owners do not use improved technologies. 
Quddus (2012) Bang. J. Anim. Sci. 41 (2): 124- 135

Table 6. Correlation matrix of the variables included in the model

\begin{tabular}{|c|c|c|c|c|c|c|c|c|c|c|}
\hline Variable & $\mathrm{X}_{1}$ & $X_{2}$ & $x_{3}$ & $X_{4}$ & $X_{5}$ & $X_{6}$ & $X_{7}$ & $\mathrm{X}_{8}$ & $\mathrm{X}_{9}$ & $\mathrm{X}_{10}$ \\
\hline $\mathrm{X}_{1}$ & 1 & & & & & & & & & \\
\hline$x_{2}$ & $0.18^{*}$ & 1 & & & & & & & & \\
\hline$x_{3}$ & -0.04 & $0.15^{*}$ & 1 & & & & & & & \\
\hline$X_{4}$ & 0.09 & $0.49 * *$ & 0.14 & 1 & & & & & & \\
\hline$X_{5}$ & 0.13 & $0.42 * *$ & $0.26 * *$ & $0.44 * *$ & 1 & & & & & \\
\hline$X_{6}$ & 0.14 & $0.32 * *$ & $0.34 * *$ & $0.36 * *$ & $0.55^{* *}$ & 1 & & & & \\
\hline$X_{7}$ & -0.01 & $0.19 * *$ & 0.13 & $0.24 * *$ & $0.34 * *$ & $0.33 * *$ & 1 & & & \\
\hline$X_{8}$ & 0.10 & $0.25 * *$ & 0.08 & $0.20 * *$ & $0.23^{* *}$ & $0.23 * *$ & $0.22^{* *}$ & 1 & & \\
\hline$X_{9}$ & 0.06 & $0.26 * *$ & 0.12 & $.029 * *$ & $0.20 * *$ & $0.24^{* *}$ & 0.15 & $0.35 * *$ & 1 & \\
\hline$X_{10}$ & $0.23 * *$ & $0.32 * *$ & $-0.41 * *$ & $0.32 * *$ & 0.06 & -0.04 & 0.10 & $0.15^{*}$ & 0.11 & 1 \\
\hline
\end{tabular}

Table 7. Results of logistic regression analysis

\begin{tabular}{|c|c|c|c|}
\hline Characteristics & $\beta$ & OR & $95 \% \mathrm{Cl}$ \\
\hline $\begin{array}{l}\text { Age (Year) } \\
\quad<30 \\
30-49 \\
50+\end{array}$ & $\begin{array}{l}-0.555 \\
-0.443 \\
\end{array}$ & $\begin{array}{l}1 \\
0.574 \\
0.642 \\
\end{array}$ & $\begin{array}{l}0.08-4.17 \\
0.08-5.17 \\
\end{array}$ \\
\hline $\begin{array}{l}\text { Education level } \\
\text { Illiterate } \\
\text { Primary } \\
\text { Secondary+ } \\
\end{array}$ & $\begin{array}{l}0.817 \\
2.276 \\
\end{array}$ & $\begin{array}{l}1 \\
2.264 \\
9.733 \\
\end{array}$ & $\begin{array}{l}0.59-8.71 \\
1.45-65.1 \\
\end{array}$ \\
\hline $\begin{array}{l}\text { Farm size } \\
<0.20 \text { ha } \\
0.20-0.99 \\
1 \text { ha }+\end{array}$ & $\begin{array}{l}-0.497 \\
-2.828 \\
\end{array}$ & $\begin{array}{l}1 \\
0.608 \\
0.059\end{array}$ & $\begin{array}{l}0.13-2.80 \\
0.01-0.63\end{array}$ \\
\hline $\begin{array}{l}\text { Household income } \\
<5000 \\
5000-14999 \\
15000+\end{array}$ & $\begin{array}{l}2.257 \\
1.725\end{array}$ & $\begin{array}{l}1 \\
9.553 \\
5.610\end{array}$ & $\begin{array}{l}2.39-38.2 \\
1.10-28.7\end{array}$ \\
\hline $\begin{array}{l}\text { Earning member } \\
\begin{array}{l}1-2 \\
>2\end{array}\end{array}$ & 1.33 & $\begin{array}{l}1 \\
3.794\end{array}$ & $0.63-22.9$ \\
\hline $\begin{array}{l}\text { Experience (Year) } \\
<10 \\
10-20 \\
20+\end{array}$ & $\begin{array}{l}1.729 \\
1.921 \\
\end{array}$ & $\begin{array}{l}1 \\
5.632 \\
6.830 \\
\end{array}$ & $\begin{array}{l}0.71-44.8 \\
0.99-47.1 \\
\end{array}$ \\
\hline $\begin{array}{l}\text { Credit received } \\
\text { No } \\
\text { Yes }\end{array}$ & 0.201 & $\begin{array}{l}1 \\
1.223\end{array}$ & $0.22-6.72$ \\
\hline $\begin{array}{l}\text { Extension service } \\
\text { No } \\
\text { Yes }\end{array}$ & $\begin{array}{l}\text { ceived } \\
0.384\end{array}$ & $\begin{array}{l}1 \\
1.469\end{array}$ & $0.25-8.75$ \\
\hline $\begin{array}{l}\text { Livestock as a ma } \\
\text { No } \\
\text { Yes }\end{array}$ & $\begin{array}{l}\text { source o } \\
2.895 \\
\end{array}$ & $\begin{array}{l}\text { income } \\
1 \\
18.07 \\
\end{array}$ & 2.93-11.1 \\
\hline $\begin{array}{l}\text { Zone } \\
\text { Hilly } \\
\text { River-flooded } \\
\text { Semi-urban }\end{array}$ & $\begin{array}{l}2.653 \\
4.796\end{array}$ & $\begin{array}{l}1 \\
14.19 \\
12.13\end{array}$ & $\begin{array}{l}2.04-98.7 \\
11.6-12.5\end{array}$ \\
\hline
\end{tabular}

Improved technologies were adopted mostly by small farm holders because semi-urban farmers of this study used technology and most of them belonged to farm-size $<0.20$ ha. Odds ratio of logistic analysis interpret that farmers belonged to middle income group (monthly income Tk.5000 to Tk.15000) was more technology adopters compared to other groups.

Analysis also interprets that credit receivers adopted 1.22 times more likely than non-credit receivers and extension service receivers adopted 1.47 times more likely than non receivers. Farmers having higher education, more earning members, resided in urban region and whose 'main source of income is dairy farming' are more likely to improved dairy technologies. Finally, surprising results (very high odds ratio) obtained in case of farmers whose main source of income was dairy farming because they depends on dairy farming and hence they invested all possible measures of dairy technologies.

\section{Constraints}

In the process of decision making for adoption, farmers decide to adopt the innovations. Hence they face a number of problems. An attempt has been made to identify various constraints faced by both types of dairy farmers (adopters and non-adopters) in adoption of various improved practices in the area of breeding, feeding, management, healthcare and socioeconomic. The results have been tabulated and presented in Table 8 under heading of the above areas. In the category of general problems faced by the farmers, high price of inputs was ranked one and no technical assistance or extension services was ranked two. About 58.3, 43.3, 40.0 and 29.4\% farmers opined that they faces inadequate knowledge of technology use, high rate of calf mortality, lack of awareness of technology use and life risk of milch animals respectively. 


\section{Adoption of dairy farming technologies}

Table 8. Constraints in adoption of dairy cattle technologies as perceived by respondents $(\mathrm{N}=180)$

\begin{tabular}{|c|c|c|c|c|}
\hline & Constraints & Frequency & Percent & Rank \\
\hline \multirow[t]{7}{*}{ I } & General & & & \\
\hline & Inadequate knowledge of technology use & 105 & 58.3 & III \\
\hline & Lack of awareness of technology use & 72 & 40.0 & V \\
\hline & No technical assistance or extension services & 116 & 64.4 & II \\
\hline & Life risk of milch animals & 53 & 29.4 & VI \\
\hline & High rate of calf mortality & 78 & 43.3 & IV \\
\hline & High price of inputs & 132 & 73.3 & 1 \\
\hline \multirow[t]{9}{*}{ II } & Breeding & & & \\
\hline & Inadequate knowledge of Al services & 55 & 30.5 & VIII \\
\hline & III equipped Al centre and negligible services at Al centre & 118 & 65.5 & I \\
\hline & Al centre is located far from farmers house & 92 & 51.1 & IV \\
\hline & Crisis of meritorious and clean semen & 102 & 56.7 & 111 \\
\hline & Unskilled technician who failed to deposit semen at the right place & 80 & 44.4 & V \\
\hline & Lack of pedigree bulls for natural service & 64 & 35.5 & VII \\
\hline & Right breed not in right place & 69 & 38.3 & VI \\
\hline & Lack of knowledge about time of mating & 110 & 61.1 & II \\
\hline \multirow[t]{7}{*}{ III } & Feeding & & & \\
\hline & Non availability of green and dry fodders & 48 & 26.7 & V \\
\hline & Under feeding due to limited financial resources & 103 & 57.2 & III \\
\hline & Inadequate knowledge about proper feeding and balanced ration & 146 & 81.1 & 1 \\
\hline & Poor availability of concentrates and mineral mixtures in village & 101 & 56.1 & IV \\
\hline & High price of concentrates & 115 & 63.9 & II \\
\hline & Unavailability of seeds and fodder during floods & 39 & 21.7 & $\mathrm{VI}$ \\
\hline \multirow[t]{7}{*}{ IV } & Management & & & \\
\hline & Poor knowledge of farmers about scientific animal management & 87 & 48.3 & IV \\
\hline & Lack of knowledge, scope and time to manage scientific shed & 106 & 58.9 & 1 \\
\hline & Lack of grazing place and space for shed & 75 & 41.7 & VI \\
\hline & Problems of labour for take care and management & 88 & 48.9 & III \\
\hline & Lack of awareness of de-worming of milch animals & 100 & 55.5 & II \\
\hline & Poor knowledge about clean milk production & 82 & 45.5 & $\mathrm{~V}$ \\
\hline \multirow[t]{8}{*}{$\mathrm{V}$} & Health care & & & \\
\hline & Poor knowledge of farmers about health care of animals & 127 & 70.5 & II \\
\hline & Lack of awareness and knowledge about importance of vaccination & 58 & 32.2 & $\mathrm{VI}$ \\
\hline & Unavailability of adequate veterinary services & 85 & 47.2 & IV \\
\hline & High charge levied by veterinary staff for medical assistance & 55 & 30.5 & VII \\
\hline & Unavailability and high cost of medicines and disinfectants & 66 & 36.7 & V \\
\hline & Distant location of veterinary hospital from farmers house & 109 & 60.5 & 111 \\
\hline & No provision for testing of animals & 142 & 78.9 & I \\
\hline \multirow[t]{6}{*}{$\mathrm{VI}$} & Socioeconomic & & & \\
\hline & Lack of capital for investment in animal, shed and feeds & 85 & 47.2 & IV \\
\hline & Lack of credit facilities and high rate of interest & 76 & 42.2 & V \\
\hline & Poor education to adopt scientific husbandry practices & 96 & 53.3 & III \\
\hline & Lack of knowledge in making value added dairy products & 112 & 62.2 & II \\
\hline & Lack of dairy cooperative societies & 152 & 84.4 & 1 \\
\hline
\end{tabular}

Proper and better care of breeding stock helps in developing good dairy herd and getting good returns too. A large number of cattle breeding technologies have been adopted recent years but still there have so many constraints are facing by the small farm holders. The major breeding constraints $(65.5 \%)$ whose rank first reported in non-adoption of improved breeding practices were ill equipped and negligible services at Al centre, followed by lack of knowledge about time of mating $(61.1 \%)$, whereas 56.7 percent respondents realized that crisis of meritorious and clean semen and its ranked third. The finding of the first constraint is supported by Vyas and Patel (2001) and Kumar et al. (2009). Other breeding constraints were Al centre is located far 
from farmer's house (51.1\%), unskilled technician who failed to deposit semen at the right place $(44.4 \%)$, right breed not in right place $(38.3 \%)$, lack of pedigree bulls for natural service $(35.5 \%)$ and inadequate knowledge of Al services $(30.5 \%)$. Insufficient technical knowledge is an obstacle for rearing crossbred cattle a part from biological adaptability issue of exotic inheritance (Quddus and Amin 2010).

Proper feeding of milch animals is one of the bases for successful dairy farming. The balance food is helpful in enhancing milk production and productivity. A profitable dairy business should not only have genetically high yielder, but also should have provision for feeding to milch animals with return. Majority of respondents $(81.1 \%)$ had inadequate knowledge about proper feeding and balanced ration to milch animals, followed by high price of concentrates $(63.9 \%)$, whereas under feeding due to limited financial resources $(57.2 \%)$. These findings were in close accordance with the most of finding of Pal (2006), Kumar et al. (2009) and Kumar et al. (2011). Other feeding constraints were poor availability of concentrates and mineral mixtures in village, non availability of green and dry fodders and unavailability of seeds and fodder during floods.

Better management and proper health care of dairy animals is important for maintaining higher productivity. Lack of knowledge, scope and time to manage scientific shed was the major hurdle (59\%) under the subhead of dairy management followed by lack of awareness of de-worming of milch animals $(55.5 \%)$. In addition to these problems of labour for take care and management $(48.9 \%)$, poor knowledge of farmers about scientific animal management $(48.3 \%)$, poor knowledge about clean milk production $(45.5 \%)$ and lack of grazing place and space for shed $(41.7 \%)$ were the major managerial constraints of dairy development and causes of non-adoption of improved practices in the study area. These findings are in partial agreement with Mohi and Bhatti (2006) where problem of labour was faced by $52.5 \%$, lack of space $48.5 \%$, lack of time to manage scientific shed $44.2 \%$ and lack of knowledge $36.7 \%$. Kumar et al. (2011) found that problem regarding lack of knowledge about scientific dairy management by $76.7 \%$ and poor knowledge about clean milk production by $72.0 \%$ farmers.

No provision for testing of animals was the first and poor knowledge of farmers about health care of animals was the second major constraint regarding health care of dairy development. In addition to these constraints, $60.5 \%$ farmers opined that distant location of veterinary hospital from farmer's house was a problem of scientific treatment. Unavailability of adequate veterinary services $(47.2 \%)$ and unavailability and high cost of medicines and disinfectants (36.7\%) were the next stage of major constraints regarding health care of dairy development. These two constraints were faced by $48.3 \%$ and $43.3 \%$ members of "Punjab Dairy Farmers Association" respectively (Mohi and Bhatti, 2006). Also lack of awareness and knowledge about importance of vaccination and high charge levied by veterinary staff for medical assistance were the important constraints of dairy technologies as perceived by one third of the respondents.

As evident from Table 8 that majority of respondent $(84.4 \%)$ reported that there was no any dairy cooperative society in the study areas which was a serious problem for proper milk marketing and take initiative to technology adoption. This finding seeks support from Kumar et al. (2011). It is also evident from Table 8 that a major portion of respondent $(62.2 \%)$ had not knowledge about conversion of milk into value added products as they were not getting sufficient profit from milk. Other constraints regarding socioeconomic aspects were poor education to adopt scientific husbandry practices $(53.3 \%)$, lack of capital for investment in management $(47.2 \%)$ and lack of credit facilities and high rate of interest $(42.2 \%)$. Unavailability of technology, lack of training and finance were mentioned as important constraints for technology uptake (Mekonnen et al. 2009). Lack of knowledge (Chagunda et al. 2006) and livestock feed (Kelay 2002) were the most important constraints in dairy development.

\section{Conclusion and I mplications}

The level of technology adoption by smallholder dairy farmers is unsatisfactory and is highly dependent on farmer's education, farming experiences, financial status and extension services. The socioeconomic circumstances influence adoption of technologies to a great extent, and these factors are the ones that determine the unique adoption process in any adoption study. Each of the improved management practices was associated with higher milk yield but adopters of a particular technology were also the adopters of other management practices, so need to sort out the 
influence of a particular management practices. Training programme should be conducted to improve the knowledge of farmers about advantages of Al services, better keeping of cross breed cattle, better management of milch animals and techniques of clean milk production, so that milk production and productivity could be enhanced. Dairy scientists, Upazilla Livestock Officer (ULO), Veterinary Surgeon and related extension officers must periodically contact with farmers to increase awareness of scientific dairy farming to boost up their knowledge in the adoption of improved dairying. Department of livestock Services (DLS) must conduct vaccination, de-worming, health care programmes with the help of ULO in order to create awareness as well as improve knowledge among the farmers, may conduct demonstration of high yielding variety of feed and fodder and make low cost balanced ration from the available resources. Due to submersion of most of the parts of riverside's low-land area during flood, alternative arrangement should be done by the government agencies for ensuring availability of feed and fodder for milch animals.

III equipped and poor result of $\mathrm{Al}$ and lack of knowledge about time of mating are the most important constraints of breeding practices. High price of inputs specially concentrates; lack of capital and knowledge about proper feeding and balanced ration; and testing of animals were the important managerial constraints perceived by dairy farmers. There is still a large scope for improvement in adoption of recommended dairy practices because of the farmer being progressive and more aware of recommended dairying, especially, in semi-urban areas. The constraints encountered in this study were due to the weak economic position of farmers and lesser economic incentives from government to promote dairy farming. Techniques of clean milk production, value added dairy products which are locally popular so that farmers in the study area may improve their knowledge and try to adopt the recommended dairy farming practices. Extension services should be increased and strengthened and mass media/ telecast programme for improved technology should be started and strengthened for transfer of improved dairy farming practices to the needy farmers in enriching their knowledge.

\section{Acknowledgement}

The author gratefully acknowledges the financial support of BAURES in conducting the research.

\section{References}

Benin S, Pender J and Ehui S (2003). Policies for sustainable land management in the East African highlands. Socioeconomics and Policy Research Working Paper 50. International Livestock Research Institute (ILRI), Nairobi, Kenya: 90-95.

Chagunda MGG, Msiska ACM, Wollny CBA, Tchalc II and Banda JW (2006). An analysis of smallholder farmers' willingness to adopt dairy performance recording in Malawi, Livestock Research in Rural Development 18

Cicek $\mathrm{H}$, Tandogon $\mathrm{M}$, Terzi $\mathrm{Y}$ and Yardimci $\mathrm{M}$ (2007). Effects of some technical and socioeconomic factors on milk production costs in Dairy enterprise in Western Turkey. World J. Dairy and F. S. 2(2): 69-73.

Devendra C (2002). Crop-animal systems in Asia: future perspectives. Agric. System 71: 179-186.

Feder GR, Just RE and Zilberman D (1985). Adoption of agricultural innovation in developing countries: A survey. Econ Dev. and Cult. Change 33: 255-298.

Halakatti SV, Kamaraddi V and Gowda DSM (2007). Determinants of dairy farming technologies by rural women under SGSY scheme. Kamataka J. Agric. Sci. 20(2): 323-325.

Irungu $\mathrm{P}$, Mbogoh SG, Staal SG and Njubi D (1998). Factors influencing the adoption of Napier grass in smallholder dairying in the highlands of Kenya. Proceedings of a BSAS/KARI/APSK/ILRI international conference held at KARI conference centre, Nairobi, Kenya, 27-30 January 1998.

Jera R and Ajayi OC (2008). Logistic modeling of smallholder livestock farmers' adoption of tree-based fodder technology. Agrekon, 47: 379-382.

Kelay B (2002). Analysis of dairy cattle breeding practices in selected areas of Ethiopia. PhD Thesis, Humboldt University of Berlin, Department of Animal Breeding in the tropics, Berlin, Germany: 6-108.

Khan MJ, Peters KJ and Uddin MM (2009). Feeding strategy for improving dairy cattle productivity in small holder farm in Bangladesh. Bang. J. Anim. Sci. 38: 6785.

Khanal AR, Gillespie J and MacDonald J (2010). Adoption of technology, management practices, and production system in US milk production. J. Dairy Sci. 93: 60126022.

Kumar J, Kumar B and Kumar S (2011). Constraints perceived by farmers in adopting scientific dairy farming practices in Madhuni district of Bihar. Research J. Agric. Sci. 2: 142-145. 
Kumar S, Hindustani S, Kateryar KM and Sankhala S (2009). Constraints perceived by farmers in adopting scientific dairy farming practices in Banka district of Bihar. Indian J. Dairy Sci. 62: 131-134.

Luthi NB, Fabozzi L, Gutier P, Trung PQ and Smith D (2006). Review, analysis and dissemination of experiences in dairy production in Vietnam: FAO. A living from livestock.

Man NV (2001). Better use of local forages for dairy cattle in Vietnam: Improving grasses, rice straw and protein rich forages, Dissertation. Uppsala: Swedish University of Agricultural Sciences, Sweden.

Mandal GK, Mandal MAS and Rahman MS (2009). Production and marketing of milk in some selected areas of Serajgonj district. Bang. J. Agric. Econ. 32(1-2): 105-115.

Mekonnen H, Dehninet G and Kelay B (2009). Dairy technology adoption in smallholder farm in Dejen district, Ethiopia. Tropical Animal Health and Production.

Metz T, Kiptarus J and Muma M (1995). Diffusion of dairy technologies in six districts of Kenya: A survey of smallholder dairy farmers in Kakamega, Uasin Gishu, Nandi, Kiambu, Nakura, and Nyeri districts. Monitoring and Evaluation Unit, National Dairy Development Project, Ministry of Agriculture, Livestock Development and Marketing, Nairobi, Kenya.

Mohamed AM, Ahmed SE and Yemesrach A (2004). Dairy development in Ethiopia. EPTD discussion paper No. 123, International Food Policy Research Institute, Washington, DC, USA.

Mohi AK and Bhatti JS (2006). Constrained encountered by dairy farmers in adoption of improved dairy farming practices. J Dairying and H.S. 25: 47-50.

Nicholson CF, Thornton PK, Mohammed L, Muinga RW, Mwamachi DM, Elbasha EH, Staal SJ and Thorpe W (1999). Smallholder dairy technology in coastal Kenya: An adoption and impact study. ILRI Impact Assessment Series 5, International Livestock Research Institute, P.O. Box 30709, Nairobi, Kenya.

Nkonya E, Schroeder T and Norman D (1997). Factors affecting adoption of improved maize seed and fertiliser in Norhern Tanzania. J. Agric. Econ. 48: 1-12.

Pal S (2006). Study on dairy livestock feeding and health care practices among dairy entrepreneurs in Burdwan district of West Bengal. Unpublished M. V. Sc. Thesis, NDRI, Karnal.

Quddus MA and Amin MR (2010). Constraints of native cattle genetic resource conservation and features of breeding system in representative areas of Bangladesh. J. Bang. Agric. Univ. 8: 113120.

Reynolds L, Metz T and Kipalarus J (1996). Smallholder dairy production in Kenya. World Animal Review 87-1996/2, http: / www.fao.org/docrop/W2650T/w265 ot00.

Sathiadhas R, Noble D, Immanuel S, Jayan KN and Sadanandan S (2003). Adoption level of scientific dairy farming practices by IVLP farmers in the coastal agro ecosystem of Kerala. Indian J. of Social Research 44: 243-250.

Shivamurthy $M$ and Nataraju MS (1994). Adoption pattern of dairy innovation. J. Extn. Edu. 5: 984-991.

Staal SJ, Baltenweck I, Waithaka MN, deWolff T and Njoroge L (2002). Location and uptake: integrated household and GIS analysis of technology adoption and land use, with application to smallholder dairy farmers in Kenya. J. Agric. Econ. 27: 295-315

Suzuki K (2005). Investigation into the constraints to dairy cattle health and production in Northern Vietnam. Dissertation. London: The Royal Veterinary College.

Toolsee P and Boodoo AA (2001). Increasing smallholder milk production through adoption of concentrate supplementation and the high adoption rate of the technology. Food Animal Research Council, Reduit, Mauritius, P. 249-252.

Uddin MM, Sultana MN, Ndambi OA, Hemme T and Peters KJ (2010). A farm economic analysis in different dairy production systems in Bangladesh. Livestock Research for Rural Development. 22: 122.

Vyas HU and Patel KF (2001). Constraints faced by milk producers in adoption of dairy technology. Rural India. 64: 111-118. 